\title{
From Teaching of Sundanese's Teenager Speaking Ability in Batam: Spoken Discourse Analysis
}

Frangky Silitonga ${ }^{1}$, Lilis Puji Astuti ${ }^{2}$

1. Universiti Tun Hussein Onn Malaysia, Johor, Malaysia

2. Universitas Putera Batam, Batam, Indonesia

Email: frangkyka@gmail.com

How to cite this paper: Silitonga, F., \& Astuti, L. (2018). From Teaching of Sundanese's Teenager Speaking Ability In Batam: Spoken Discourse Analysis. International Journal of Language Teaching and Education, 2(3), 325-333.

https://doi.org/10.22437/ijolte.v2i3.5182

Accepted: October 18, 2018

Published: November 30, 2018

Copyright (c) International Journal of Language Teaching and Education.

This work is licensed under the Creative Commons Attribution International License (CC BY 4.0).

http://creativecommons.org/licenses/by/4 $.0 /$

\section{Abstract}

The local language is a language used as a characteristic of a tribe or certain people in a region. It is used as a communication tool in daily life of a tribe who lived either on a small area, province or a wider area. The existence of local language is closely related to the existence of tribe and culture which is generated from one generation to another. Sundanese is one of local languages in Indonesia, which become the main supporting element of the traditions and customs of the Sundanese. The ability to speak Sundanese is one of the important aspects to preserve the Sundanese culture. The use of Sundanese lin daily conversation in a family will root the way of life and habits of children in the Sundanese family. It aims at maintaining love toward their ancestor language. Some Sundanese families in Batam, including the teenager, think that the Sundanese language is not necessary to be learnt at this era. Some reasons were because it is not taught in school, not a requirement in entering college, and not considered as a priority language to seek for job. As a result, Sundanese will slowly disappear from the Sundanese people. From the observation, it is found that only few of families are aware about the importance of maintaining Sundanese as prime culture. The observation to 11 (eleven) teenagers shows that only $24 \%$ of participants have the ability in speaking Sundanese.

\section{Subject Areas}

Discourse Analysis

\section{Keywords}

Discourse, Sundanese, Spoken, Teenager

\section{Introduction}

In general discourse analysis, the language is the cultural heritage of the ancestors which is used as a primary communication tool by humans. Through the language we can distinguish cultures and tribes one from another. A tribe without the Native language is just like a tree without fruit, New Testament 
(Matthew 7: 16-18). Just as the trees which identified by its fruit, a nation is recognized by the language used. Language characterizes the identity of the nation. Some experts say that language is a central element and expression of identity and the importance key to preserve group identity. The main function of language is as a tool of communication (Mulyati et al, 2014)". Discourse as a communication will be effective if both parties (communicants and communicators) have common understanding regarding the language and how to use it. Without understanding, the language has no meaning and may be misunderstood. There are seven functions of language according to Mulyati at al cited Halliday (2014); 1) Instrumental, Language is used as a tool to gain needs (e.g. "I want a slice of apple pie"). 2) Regulatory, language is used to control or to tell others what to do (e.g. "go to library quickly"). 3) Interactional, language is used to make contact with others and to form relation (e.g. "how are you, dear “.), 4) Personal, language is used to express feeling (e.g. "I am happy"), 5) Heuristic; language is used to gain knowledge about the environments (e.g. "what is the function of the microscope?"). 6) Imaginative, language is used to create ideas. Here language is used to tell stories, to write novels, and to make jokes. 7) Informative, the use of language to convey information. Language is an identity of the nation (http://badanbahasa.kemdikbud.go.id). In other word, the existence of the nation or tribe can be represented through the language used. Language plays an important role in the development of culture. This form is very important because the language deliver the culture by generation to generation. Indonesian local languages should be preserved so they will not be disappeared and displaced by other foreign languages. The nation and tribe have their specific identity. As a communication and social tool, language is placed as main thing in human life.

In term of language, Indonesia is one of the countries that have variety of languages which come from the diversity of culture and tribe as well. Each of tribe has their own unique and distinctive identity which is different from one and another. Based on the results of the 2010 population census, Indonesia have about 2,500 languages, or nearly twice the number of types of tribes that reached as much as 1,340 nations. (BPS, 2010). One of them is Sundanese. One of the unique characteristic of Sundanese is language's manner (undak-usuk basa) which barely possessed by other languages and also the intonation in using the language, which known a lentong" (during speaking of language level, the speakers also have to use the rhythm to make it harmony) (Wibisana, 2011). In addition, lentong is the composition of words to form a sentence, when spoken will be heard have a rule drops or rises interspersed with long pauses or short. That is, in pronouncing sentence it always refers to songs describe the content or meaning of the phrase or sentence. 
The writer, who has been living in Batam Island for almost 20 years, found out that some children whose both parent are pure Sundanese tribe or half Sundanese (which only mother or father is Sundanese), hardly either to speak or to understand Sundanese. According Ekadjati (1993), children whose both parents or one of parent still use Sundanese connotation. The second concept is the basis of culture. People who are not Sundanese origin but raised in Sundanese way, they ended up loving Sundanese. They can be called as the Sundanese. One of the Sundanese book's author, Wibisana (2011), said that "apan basa the ciciren bangsa, kusabab kitu eksistensi urang sunda gumantung kana sikepna ngamumule basa indungna" (the language is an identity of the tribe, therefore the Sundanese tribe's existence is depend on how Sundanese people preserve its mother tongue). UN Educational, Scientific and Cultural Organization (UNESCO) in (http://www.ibtimes.co.uk/unesco-half-worldslanguages-will-disappear-by-2100-1498154) had predicted that half of the world's languages will be extinct by the end of this century. The organization warned that over 2,000 of the 7,000 official languages used around the world have only 1,000 speakers or fewer. This matter has motivated the writer to write the Term paper based on a theme "Sundanese Teenager speaking ability in Sundanese family in Batam". This research aims to know how far the teenagers understand to respond in Sundanese conversation and the reason behind it.

\section{Literature Review}

\subsection{The Definition of Language}

Leeuwen states that critical discourse analysis model related to event and social agent in certain groups are exposed in news. This model tries to investigate the marginal group in discourse (Oktavia \& Silitonga, 2016). Generally, people use language in daily life for communication. Language is an expression that contains a view to communicate with others. Something is meant by speaker can be understood by the listener or the speaker expressed through language. The definition of language is varying. There are many statements from the expert about the definition of language. Webster's New Collegiate Dictionary (1981) "Language is a systematic means of communicating ideas or feelings by the use conventionalized signs, sounds, gestures or marks having understood meaning". In other word, language is a tool to express feeling or ideas either by words, sign, or gestures which can be understood by the interlocutors. Language is a group of sounds which arranged orderly and pronounced orally. It is uttered to express thoughts (Bahasa Indonesia, 2014). It means that language is a verbal communication to convey ideas. Language is the key to unlock the treasures of knowledge. By the language, we can master science and technology. (Bahasa Indonesia, 2014). Language is the main 
instrument to acquire knowledge, science, and technology. Language is arbiter which has seven characteristic (Bahasa Indonesia, 2014). They are; Language is beautiful; In essence the language is a sound. If this sounds conveyed by blending the sound of the vowel or a consonant will produce a beauty that is not owned by other. The beauty of the language is because the variety sound blended between vowels and consonants come out together instead of monotone sound such as an animal produces; guk guk guk, meow meow meow. A culture tends to be kept alive; it has to be passed on from one generation to the next generation. In order for this cultural inheritance went smoothly, psychologically necessary social awareness and the willingness of the previous generation and the readiness or the willingness of the next generation. However, there some important factors need to be considered in order this culture inheritance, one of them namely the ability to speak its language accordingly. Through the language this cultural inheritance could take place. Language and culture is as two sides of a coin, which always closely intertwined. If one exist, the other was alive, otherwise if one dies the other is dead.

According to Cambridge dictionary, the definition of teenager is a person whose age between 13 to 19 years old. The teenager period is called adolescence. It is a transition period from childhood to adulthood. On this period, some changes occur in term of hormonal, physical, psychological and social. Adolescent phase is an important development period of the individual life which teenagers' body stretched from the end of childhood to early adulthood. It has a direct impact and long-term impact that happened during this period. In addition, this period also has an important impact on physical and psychological development of individuals, where there is physical and psychological development of rapid and important. In this period, it requires a child to leave the properties of infantile and must learn new patterns of behavior and attitudes. During the transition in this period, a person is often confused because they are in demand to behave in accordance with his age, but on the contrary if the individual tries to behave like adults, people often say that they behave too mature for their age. In this period, an adjustment to the peer group has an important role for teenagers. They were trying to find identity with the outfits, speaking style and behave as similar to other. One way to convince their teens is by using a status symbol, such as cars, clothes and other objects that can be seen by others. Adolescence is an opportunity for children and a pivotal time for us to build on their development in the first decade of life, to help them navigate risks and vulnerabilities, and to set them on the path to fulfilling their potential, UNICEF (Adolescence an Age of Opportunity, 2011). This period is called a critical time in which the role of parents, the environment, education, and the community give large impact on their future and the nation. Sutardi (2012) mentioned that adolescence is a critical 
period that will determine the future of a person.

\subsection{Speaking Ability}

Yule (2010) stated that child acquires language principally through a process of imitating adult. Base on the theory, it is concluded that an ability to speak is not learned inheritance. The process of language acquisition has some basic requirements. In order to speak a language, a child must be able to hear the language used. They develop listening competence before they develop the ability to speak. Their ability to listen is acquired because children are required to respond the spoken language from their parent. Richards \& Rodgers (2001) stated that once foundation in listening comprehension has been established, speech evolves naturally and effortlessly out of it. In case of speaking Sundanese, children have to be introduced into Sundanese as earlier as possible. When Sundanese is formed into habit in daily conversation, it will last for long time in their brain.

\subsection{Teenagers Restriction to Speak Sundanese}

Parents are those who contact directly with their children. There is famous Sundanese proved said that "anak merak kukuncungan, uyah mah tara tees ka luhur" (Children naturally mimics the nature and character of their parents). Related to the teenagers' ability in speaking Sundanese, parent is a main role for the children. When the parents have no interest to speak their mother tongue, their children will also not interest. This case happened in Batam where the community is heterogenic that the major language used is Bahasa Indonesia. Moreover, while parents are working, they leave their baby to the caregiver who is not Sundanese. So, the caregiver will communicate with the baby with common language. Additionally, Sundanese is not taught in Batam School as a local language as part of the curriculum. Foreign language such as English and Mandarin attract parents and teenager's attention more than Sundanese language. Parents are proud having children who have ability in speaking foreign language rather than speak their local language. The teenagers also are not interested to learn their local language. Besides, Job field or University are not required someone to speak local language. Thus, teenagers have little interest to learn their local language.

\subsection{Sundanese Language}

Indonesia is a multilingual country which has tribe and ethnic diversity. Sundanese is one of cultures in Indonesia with a considerable population in West Java. Based on the population census in 2010, Sundanese is second most tribe in Indonesia with 15.5 percent of Indonesian population. Sundanese, called 
basa sunda, is used by people for variety of communications purposes. Sundanese was supposed to be found in 14th century based on the inscription that found in Kawali Ciamis. Many inscriptions estimated were made during the reign of King Niskala Wastukancana (1397-1475). Actually, Sundanese language has been used orally by the Sundanese community long before that era. There is a possibility that the Kw'un Lun language which has mentioned by "berita cina" used as a spoken language in the archipelago before the 10th century by the people of West Java, presumably as Sundanese (ancient), although the truth is not still unknown (West Java Tourism Department, 2015). In other perception, Sundanese term is related to Hindu culture. In literature Adiparwa, a famous first part of the book Mahabrata, was regarded holy by Hindus. It mentioned that there were two figures giant kings named Sunda and Upasunda. (Kebudayaan Sunda, 2014).

Sundanese has some dialects such Priangan, Cirebon, and Banten. Each dialect has a distinctive vocabulary, intonation, and even of its own undakusuk (language level) as well, but each dialect is able to be understood each other (Rosidi, 1984). One characteristic of Sundanese language is developed through teaching in schools and teacher education. Balai Pustaka books are also concerned about the undak-usuk(language level). Undak-usuk(language level) is divided into levels; very rough, rough, medium, polite and very polite. (Sundanesse Culture, 2015). In Indonesia dictionary, Sundanese is divided into three levels; impolite, standard and polite (Kamus Besar Bahasa Indonesia, 2010). The difference of the undak-usuk (language manner) can be seen in below sentences;

Basa lemes (Polite language)

Visitor : Punteun pa, bade tumaros di palih mana pak lurah linggih?

(Excuse me; do you know where the Village chef house is?)

Answer : Di palih kencaen tanggal jeruk anu itu, mangga ku abdi di jajapkeun, kalereusan rorompok simkuring caket ka bumi pak lurah. (In the left of that orange tree, let me accompany you. It is coincidence that my house is just nearby him)

Basa loma (Standard language)

Speaker : : Meta, nyaho teu di mana ari imah si budi?

(Meta, do you know where Budi's house is?)

My friend : Di belah kencaen tangkal jeruk. Hayu lah jeung urang indit kaditu. Kabeneran imah urang deket jeung imah manehna) (In the left of that orange tree, let me accompany you. It is coincidence that my house is just nearby him).

Basa kasar (impolite words) is used when oneself is angry or when 
someone I speaking related to their pet.

Sok tah nyatu heula (eat your food, goat),

Mangga tuang heula pa guru (Please have a meal sir / teacher), sok dahar heula meta (have your meal meta)

Batam city is located directly adjacent to Singapore and Malaysia which consists of \pm 400 islets. The total of its area is $3,990 \mathrm{~km} 2$ consisting of 1380.85 $\mathrm{km} 2$ mainland and an area of 2,950 km2 Ocean. (Batam Tourism Department, 2014). Population data in Batam per December 31, 2014 is 1,030,528 inhabitants. Batam is one of the fastest economic growth population city in Indonesia. The economic growth is average $7 \%$ greater than the national economic growth. The native of Batam Island is Malay. The cultural roots can be traced in the island of Tanjung Pinang. In 1970, Batam was designed as environment industrial areas which were supported by the Development Authority. In the 90s, the Municipality of administrative Batam changed its status to the autonomous region, named as the Batam City Government. As an industrial city, Batam is a promising object and the main destinations of job seekers from Indonesia. The number of job opportunities and high value of the minimum wage of the city attract job seekers coming to Batam. Thus, Batam is a magnetic in the eyes of both tourist and job seeker.

\section{Methodology}

The type of this research is qualitative method. Sugiyono (2011) stated that qualitative research has the natural setting as the direct source of data and the researcher as the key instrument. Non-probability sampling and precisely purposive sampling were utilized in this research.

The data were collected from junior and senior high school students. The data were gained from observation and interview. Structured observation was used to collect the data. The process of observation was noted and recorded. This research used semi-structured interview. The participants were teenagers and their parents. The teenagers were asked to answer the questions with either Sundanese or Indonesian. In the end of interview, the teenagers were questioned about what is their opinion about the topic discussed (Silitonga, 2017). After implementing the research, the researcher interviewed the parents regarding their teenagers' abilities in the speaking Sundanese skill. The researcher also carried the interview after accomplishing the research to know the parents' response toward their teenagers speaking ability.

\section{Findings and discussion}

The result is presented in two categories: "unable" and "able". The percentage shows the ability of the teenager to speak in Sundanese. 


\begin{tabular}{ccl}
\hline $\begin{array}{c}\text { Total } \\
\text { question }\end{array}$ & Percentage & Conclusion \\
\hline 14 & $42.8 \%$ & Unable \\
\hline 15 & $6 \%$ & Unable \\
\hline 15 & $20 \%$ & Unable \\
\hline 14 & $0 \%$ & Unable \\
\hline 19 & $47 \%$ & Unable \\
\hline 15 & $0 \%$ & Unable \\
\hline 16 & $6 \%$ & Unable \\
\hline 17 & $5 \%$ & Unable \\
\hline 17 & $17 \%$ & Unable \\
\hline 4 & 0 & Unable \\
\hline 13 & $100 \%$ & Able \\
\hline 159 & $76 \%$ & Unable \\
\hline
\end{tabular}

Table 4.1. Ability of the teenager to speak in Sundanese

The reasons for their inability in speaking of language in Sundanese teenagers in Batam are:

1) The parents do not use the language in daily conversation.

2) The teenagers are accustomed to use Indonesian because their environment mostly use Indonesian as daily language.

3) Lack of loyalty to the own language because they think Sundanese give no advantages in academic purpose and job field.

\section{Conclusions}

Sundanese might be disappeared from Sundanese family in Batam. It will shift to Indonesian and English. In this case, parents seem failed to inherit their local language to their children. Sundanese in Batam are preferred to learn and use the languages that give more benefit to them. It causes the Sundanese teenagers fail to recognize their identity. There are some recommendations to make Sundanese keep exists, especially in Batam. It can be started by introducing Sundanese as earlier as possible to the children through singing Sundanese song, telling Sundanese folks, watching Sundanese movies, or joining Sundanese club in Batam.

\section{References}

[1] Carstairs-McCarthy (2002). An introduction to English morphology: Words and their structure, great Britain. Edinburgh University Press Ltd. 
[2] Ekadjati, (2014). Kebudayaan sunda. Bandung: PT Dunia Pustaka Jaya.

[3] Handayani, Dhona, N., \& Silitong F. (2017). EFL students' ability to identify singular and plural nouns in paragraph. ELLITE: Journal of English Language, Literature, and Teaching.

[4] Hewings, (2013). Advance grammar in use. Italy: Cambridge University press.

[5] Koenig, M. (2002). The impact of government policies on territorially based ethnic or nationalist movements. International Journal on Multicultural Societies, 4(2).

[6] Mainizar, (2013). Marwah: Peranan orang tua dalam pembinaan dan pengembangan bahasa pada anak usia 2-6 tahun. 12(1)

[7] Mulyati at all (2014), Bahasa Indonesia, Tangerang: Universitas terbuka.

[8] Richards, J. C., Rodgers, T. S. (2011). Approaches and methods in language teaching ( $2^{\text {nd }}$ ed.). United States of America: Cambridge University Press.

[9] Sallabank, J. (2010). Language endangerment: Problems and solutions. $50-87$

[10] Saputra, S. (2007). Webster's kamus lengkap Inggris-Indonesia, Indonesia- Inggris. Batam: Karisma Publishing Group.

[11] Silitonga, F. (2017). The Teenegers' characteristics in gender written text by discourse analysis at Batam. Kajian Linguistik dan Sastra, 6175.

[12] Silitonga, Oktavia F. Y. (2017). Implementasi analisis wacana kritis perspektif Leeuwen dalam berita politik surat kabar Padang ekspres terhadap pembelajaran bahasa berbasis teks.

[13] Sugiyono, (2011). Metode penelitian kuantitatif, kualitatif dan R\&D. Bandung: ALFA BETA.

[14] Wibisana, (2011). Ngamumule basa sunda. Bandung: PT. Kiblat Utama.

[15] Yule, (2010). The study of language. New York: Cambridge University Press. 